\title{
Translation and cultural adaptation of data collection instruments on gender construction in childhood
}

\author{
Tradução e adaptação cultural de instrumentos de coleta de dados sobre construção de gênero
} na infância

\author{
Traducción y adaptación cultural de instrumentos de recolección de datos sobre la construcción de \\ género en la infancia
}

\author{
Julia Maricela Torres Esperón $n^{1,2}$ (D) \\ Ivone Evangelista Cabral ${ }^{1}($ (i) \\ Roberto José Leal ${ }^{1}(\mathbb{D})$ \\ Elisa da Conceição Rodrigues ${ }^{1}$ (1) \\ Marialda Moreira Christoffel ${ }^{1}$ (1)
}

Juliana Rezende Montenegro Medeiros

de Moraes $^{1}$ (10

1. Universidade Federal do Rio de Janeiro.

Rio de Janeiro, RJ, Brasil.

2. Escuela Nacional de Salud Publica,

Ministério de la Salud. Habana, Cuba.
Corresponding author:

Ivone Evangelista Cabral.

E-mail: icabral444@gmail.com

Submitted on $11 / 30 / 2017$.

Accepted on 02/15/2018.

DOI: 10.1590/2177-9465-EAN-2017-0371

\begin{abstract}
Gender studies on childhood imply the use of tools that, if elaborated in another country, they need to be translated and culturally adapted to Brazilian Portuguese. Objectives: To translate and adapt Cuban Spanish versions of the Encuesta de constatación y reflexión del sexismo en el ámbito escolar, and the Cuestionário auto-administrado de constatación y reflexión del sexismo en el ámbito escolar. Method: A qualitative and methodological study was developed with 37 experts (15 teachers of elementary school and 22 healthcare professionals on child health) from the Brazilian cities (Rio de Janeiro, Macaé, Itajaí, Porto Alegre) and Cuban (Habana). Results: Nine original questions of original tools were modified and adapted to the language, culture and elementary Brazilian education system. It was necessary to split the first tool into two separate parts (classroom and break) for facilitating its application by observers. Conclusion: Changes improved the deepness, consistency of observations among observers and introduced more specificity to final versions of tools for further applications on nursing and education studies.
\end{abstract}

Keywords: Method; Gender Identity; Child Health; Health Promotion.

\section{Resumo}

Estudos sobre gênero na infância implicam no uso de instrumentos que, se elaborados em outro país, precisam ser traduzidos e culturalmente adaptados para o português brasileiro. Objetivo: Traduzir e adaptar as versões cubanas da Encuesta de constatación y reflexión del sexismo en el ámbito escolar e do Cuestionário auto-administrado de constatación y reflexión del sexismo en el ámbito escolar. Método: Estudo metodológico qualitativo, desenvolvido com 37 experts (15 professoras de ensino fundamental e 22 de saúde da criança) do Brasil (Rio de Janeiro, Macaé, Itajaí, Porto Alegre) e Cuba (Havana). Resultados: Modificou-se nove questões originais desses instrumentos, adaptando-as à língua, cultura e ensino brasileiro. Foi preciso separar os instrumentos em duas partes (sala de aula e recreio) para facilitar sua aplicação. Conclusão: As mudanças melhoraram a profundidade, consistência das observações por diferentes observadores e introduziram mais especificidades às versões para aplicação futura em pesquisas de enfermagem e educação.

Palavras-chave: Métodos; Identidade de Gênero; Saúde da Criança; Promoção da Saúde.

\section{Resumen}

Los estudios sobre el género en la infancia implican el uso de instrumentos que, si se producen en otro país, deben ser traducidos y culturalmente adaptados para el portugués brasileño. Objetivo: Traducir y adaptar las versiones cubanas de la Encuesta de constatación y reflexión del sexismo en el ámbito escolar y del Cuestionario auto-administrado de constatación y reflexión del sexismo en el ámbito escolar. Método: Estudio metodológico cualitativo desarrollado con 37 expertos (15 profesoras de enseñanza fundamental y 22 profesionales de salud del niño) de Brasil (Rio de Janeiro, Macaé, Itajaí, Porto Alegre) y Cuba (Habana). Resultados: Se modificaron nueve cuestiones originales de esos instrumentos, adaptándolas a la lengua, cultura y enseñanza brasileña. Los instrumentos se separaron en do partes (aula y recreo) para facilitar la aplicación. Conclusión: Los cambios mejoraron la profundidad y consistencia de las observaciones por diferentes observadores e introdujeron más especificidades a las versiones para aplicaciones en futuras investigaciones de enfermería y educación.

Palabras clave: Métodos; Identidad de Género; Salud del Niño; Promoción de la Salud. 


\section{INTRODUCTION}

The understanding of gender as a socially constructed concept is due to the ontological belief in which is structured in values that characterize male and female social patterns in order to determine what men and women can perform in society. ${ }^{1,2}$ Such values are conveyed intergenerationally, and are reflected as in the socialization as in the children education. Therefore, the School can promote splits and introduce new mindsets from the moment in which the child has the opportunity to live in partners under the guidance of teachers and pedagogical projects oriented by equity of gender and social justice. . $^{3,4}$

There is a need to see the School as an institution capable of aligning new cultural references, given that ideologies do not arise in people spontaneously. It is one of the institutions of society promoting and introducing policies, and practices for social inclusion. Researches and publications on gender, and schooling show that institutionalization of ideas and concepts in relation to gender, reinforces the means through which gender differences are believed to be right. This process can be identified in policies, priorities and schooling practices, in different levels of education. ${ }^{5,6}$

Different instruments have been adopted to study individual preferences of boys and girls for toys and games, and their preferences for partners, to better reflect relationships and gender stereotypes ${ }^{7,8}$ than roles and gender identity that are better identified by observing social interactions in natural settings. A structured interview was conducted through instruments allowing children to classify their preferences for toys (for boys, for girls and for both), justifying their choice of each one provided in the catalogue of toys. ${ }^{7}$ In another study, conducted by two instruments, the Playmate and Play Style Preferences Structured Interview (PPPSI), and the Human Figure Drawing, boys and girls between 9 and 11 years old pointed out their preferences for partners and games. ${ }^{8}$ The study was conducted in a room (at school or outside it), in both studies, and each seated child made their choices and answered the instrument. Ethnographic studies produce records closer to reality in which gender relations happen in classrooms, kids' clubs and breaks. ${ }^{7-10}$

In the ethnographic observation introduced by the Cuban research on formation of promoters of childhood gender equity, ${ }^{10}$ in primary education schools, brought favorable results in the management of the instrument adopted by the researcher team from that country. The instruments previously mentioned, an Observation Guide and a Cuban Self-Answered Questionnaire for teachers could identify the construction of gender between boys and girls. Linguistic, cultural and educational system differences between Brazil and Cuba require rigorous methodological procedure for instruments adequacy, involving "translation" and "adaptation".

However, translation and adaptation are different terms, because on the one hand they include semantic and language processes, and expressions associated to cultural adequacy, besides translation; ${ }^{11}$ on the other hand, there may be a risk to create new instruments redundant with the other existing ones to research the same theme.

In Health and Nursing, cross-cultural adaptation is widely used because it recognizes that socio-cultural and linguistic contexts are different. Thus, cross-cultural adaptation is the change process of measure previously validated in another language, highlighting the need to equate social and cultural contexts, and life style of the target population. ${ }^{2-14}$

The situation presented points out the need to the use of ethnographic observation instruments in order to identify interactions between boys and girls in natural settings. However, if they were produced in another country, these instruments would need to be translated and culturally adapted to the Brazilian Portuguese. The goals set were to translate and adapt the Cuban version of Encuesta de constatación y reflexión del sexismo en el ámbito escolar and Cuestionário auto-administrado de constatación y reflexión del sexismo en el ámbito escolar.

\section{METHOD}

This methodological article corresponds to the first objective goal of the extensionist research-action on (de) constructing and promoting health of children at school, that has been being developed in three Brazilian municipalities belonging to the southeast (Rio de Janeiro-RJ), central-west region (Jataí-GO), and south (Porto Alegre-RS). Translating, back-translating, and adapting culturally the instruments from Cuban Spanish into Brazilian Portuguese was the first stage of this research and extension, introduced from November 2016, to May 2017. Such instruments will be used in the nature field work, when elementary school children interaction will be observed and extensionist actions will be implemented.

The cross-cultural adaptation of instruments created in other languages, and validated in other cultures requires an ultimate semantic equivalence of language and idioms, between the text and its translated version. The use of foreign instruments without the required adaptation may put in risk the validity and accuracy of instruments developed..$^{11,13}$

The version of instruments created in other languages, countries and cultures embraces a process developed in four stages: translation, back-translation, review by the Committee and pre-test. ${ }^{11}$ Even though there is no agreement, strategies of performance, cultural language, linguistic and contextual aspects corresponding to its translation should be considered in the operational synthesis patchwork of resulting procedures from different sources. ${ }^{12-14}$

In this sense, the Cuban Spanish version of the instruments Encuesta de constatación y reflexión del sexismo en el ámbito escolar and Cuestionário auto-administrado de constatación y reflexión del sexismo en el ámbito escolar, into Brazilian Portuguese was performed in four stages, as shown in Figure 1. The first three stages were introduced before the extensionist 
action project was approved, because the first version must be sent in Portuguese for the Ethics Committee analyze it. Consequently, it was carried out in November and December of 2016.

Figure 1. Stages (1 to 3) of translation and cultural adaptation of the original versions (OV) from Cuban Spanish into Brazilian Portuguese of the selfanswered (SAQ, V5) and observation questionnaires (V1 and V2; V3, V4, V6).

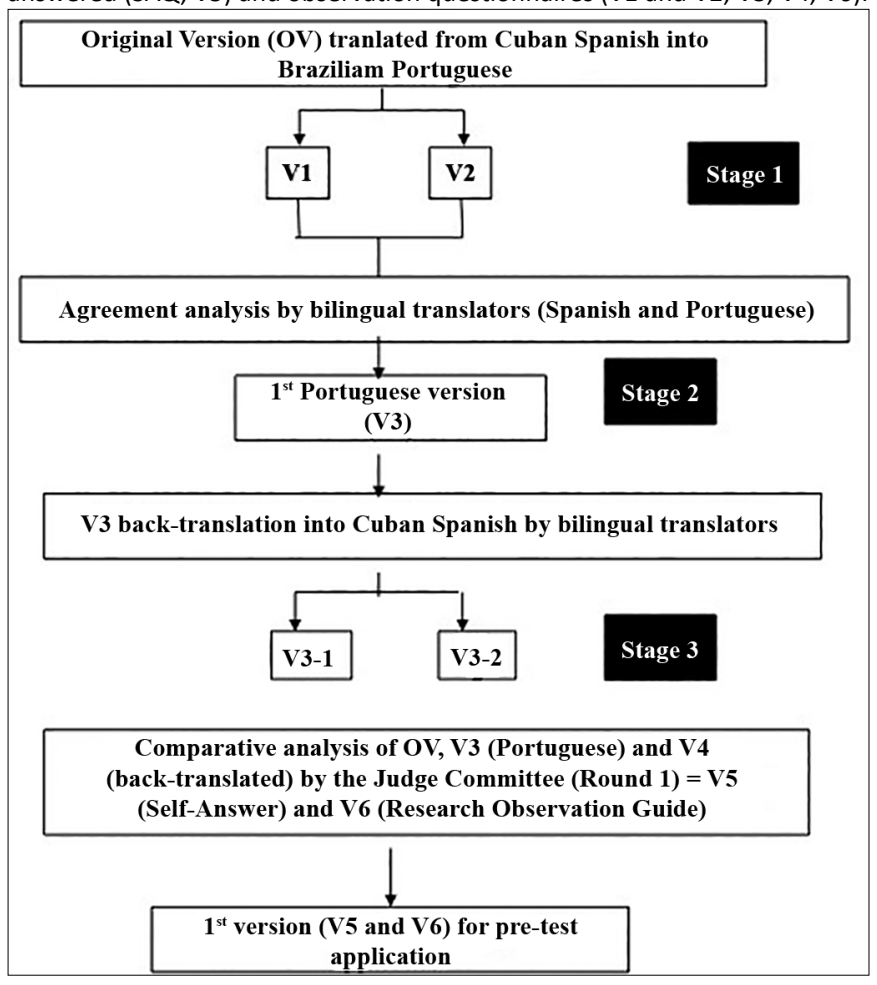

The first one was the original version's translation (OV) from Cuban Spanish, of both instruments, into Portuguese by two Brazilian students of the medical course of a University in Cuba, who had lived in that country for four and six years. Both students had linguistic and cultural dominance of the two languages (V1 and V2), and knowledge on the subject, but they were not informed of the purposes on the use of the translated material, aiming to develop the research previously mentioned. Subsequently, the agreement analysis of the two translated instruments was carried out in a single meeting with three other Brazilian students of Medicine to the first qualitative validation, when they gave their opinion on cultural adequacy of linguistic terms used. As a result, the version 3 (V3) has arisen.

The second stage, back-translation, was performed by one Brazilian and one Peruvian health professional (V3-1 and V3-2), fluent in both languages.

The original versions (OV), translated (V1 and V2=V3) and back-translated (V3-1 and V3-2) were incorporated in a comparison chart to be evaluated by the Committee of Evaluator Judges, in the third stage. This Committee was comprised of 10 people aiming to analyze language clarity, adequacy of terms to the language, gender concept and Brazilian culture. Because of this textual intervention by the Committee of Judges, besides the Spanish version (back-translation - V4), the first version in Portuguese (V5 and V6) of both instruments was produced.

The version of the back-translation, from Brazilian Portuguese into Cuban Spanish, of the Observation Guide in a primary school in Havana city (Cuba) was also applied, involving three pairs of observers, with six observation shifts, three in break time and three in the classroom in December of 2016. The system of qualitative interobserver agreement occurred at three different times and each time an observation was completed, the needs for changes were reviewed by the Committee of Judges. The final result of this stage generated SAQ in Spanish (V4), SAQ in Portuguese (V5) and Observation Guide (V6).

In the fourth stage, the Self-Answered Questionnaire (SAQ) and the Observation Guide (Figure 2) were pre-tested. The SAQ was answered by five school teachers (3) located in three different Brazilian cities - Macaé (RJ), Jataí (GO) and Porto Alegre (RS) - from February to March 2017, totaling 15 people. The Observation Guide was applied at the beginning of the school year, by 12 observers who worked in pairs, with an average time of 30 minutes of observation.

The simultaneous and independent application of the Observation Guide by the pairs of observers occurred in a public elementary school in the city of Rio de Janeiro, totaling 12 events observed in the classroom and in the break time on three different days, in the morning and afternoon shifts. After each observation shift, the field researchers gathered for item-by-item,

Figure 2. Stage 4 of cultural translation and adaptation of the Cuban Spanish versions of the Brazilian Self-Answered Questionnaire (SAQ) and the Observation Guide.

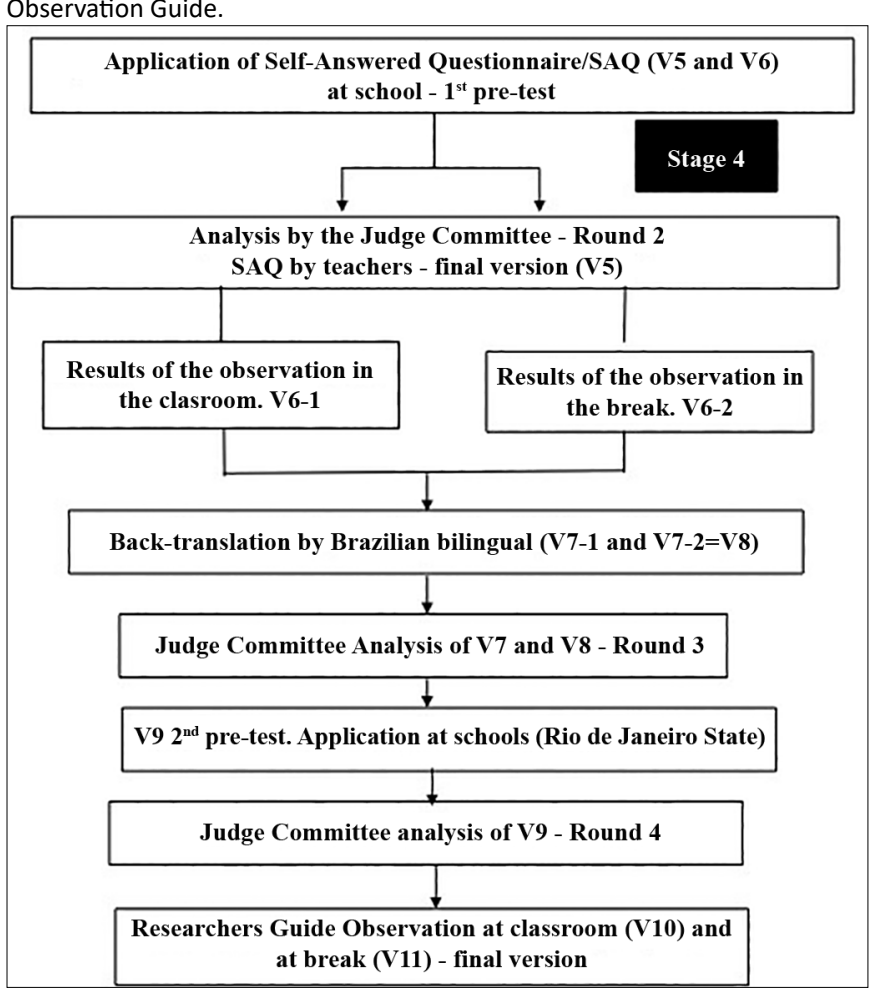


sought interobserver agreement and proposed qualitative changes in the structured record that guided the observation. It was observed children interacting with each other, who had the same age, gender, socioeconomic conditions, and they were in the same class, for whom the instruments in the original version were first applied.

In the interobservation intervals, the comparative charts returned to the Committee of Judges (Figure 2), previously mentioned, for textual and linguistic adjustments (V6 to V12), until in the fourth round there were no further needs for changes. This process lasted from February to May 2017.

The instruments address three dimensions (D), namely: interactions between students (D1), teachers and students (D2), and students and teachers (D3). These dimensions showed spatial distribution and occupation, preference for toys, social behavior, attitudes differentiated by gender, sexist language and sentimental relationships, to apprehend identity, roles, stereotypes and gender relations.

Regarding the ethical aspects of the action-extensionist research, the project was approved by the Research Ethics Committee of the Escola de Enfermagem Anna Nery/São Francisco de Assis Attention Institute (EEAN/HESFA) of the Federal University of Rio de Janeiro, under the Resolution 510 of April 7, 2016, of social sciences and health research, Opinion 1,866,131 of December 11, 2016.

Since the teachers' performance was for pre-test and the members of the Committee of Judges acted as judgment experts based on scientific knowledge and not on personal experiences and demonstrations, the Free and Clarified Consent Term (FCCT) was not applied at this stage, as expected in the approved project.

\section{RESULTS}

The 10 members of the Committee of Judges had the following qualifications: evaluation of assessment instruments, ${ }^{1}$ experience in gender studies, ${ }^{1}$ translation and technical review from Spanish into Portuguese; ${ }^{2}$ pediatric nurse ${ }^{3}$ elementary school teacher; ${ }^{1}$ researcher of the gender project understanding Brazilian Portuguese. ${ }^{2}$ Twelve observers of the children's health area, who worked in the fieldwork, joined the Committee.

Translation, back-translation and cultural adaptation of the instruments Encuesta de constatación y reflexión del sexismo en el ámbito escolar and Cuestionario auto-administrado de constatación y reflexión del sexismo en el ámbito escolar (Annex 1) was an operationalized process in successive and common stages in the three first steps. From the fourth stage on, the qualitative validation of the Committee of Judges members took place, from the translated version of the Cuestionario auto-administrado de constatación y reflexión del sexismo en el ámbito escolar, which was renamed to Questionário de Auto-Resposta de Professores para Avaliação de Sexismo no Espaço escolar - Brazilian Portuguese version (Self-Answered Questionnaire for Teachers to Evaluate Sexism in the School Environment) (Annex 1).
There were textual convergences when translating the observation guide and the SAQ (V1 and V2) by the two translators in most domains, except for three words in three questions. In back-translation, there is also consistency between translators, as they maintained the same questions standard, except the use of two terms. In this sense, the first version of the instrument into Brazilian Portuguese (Chart 1) presented to the Committee of Judges required words and expressions (sketches, map, break, playground, to need, to observe) change in three questions (I. 1, I.3, II.2). These changes were based on the opinion of experts, justifying the fact that a question can be asked without using the terms, sketch or map, changing to just draw the distribution. Another said - it is common here in Brazil to use "break" as expression, because, at that moment, children can be in the playground, in the cafeteria. Another still proposed the verbs, to observe/evaluate, because actually the two actions will be performed, instead of to need and to observe proposed by the translators.

Other proposed changes in four questions included clarifying some of the terms to improve textual understanding by adapting them to the Brazilian culture. Schools in Brazil have other people that interact with children, such as the monitor, coordinator, principal.Therefore, question I.3-g has incorporated items that address the relationships of boys and girls with other people in schools.

The dynamics of schools functioning in Brazil also led to the change of question I.3-j, hence the experts suggested more specific terms to designate aggressive manifestations, both physical and verbal. Said one - if there is a need to specify the types of aggressions, these verbal or physical terms are very unspecific. There was agreement to add an explanatory note with the following terms: insults, swear words, derogatory nicknames or otherwise - for verbal aggression; and, hits, pushes, nips, bites, kicks, punches or otherwise - for physical aggression.

Experts included an explanatory note in item II.1 to designate the tone of voice, because it is not clear what the tone of voice means. It was incorporated the phrase Voice intonation change upwards [strong] and downwards [smooth].

In the question of item II.5, the word punishment was replaced by the term disciplinary actions. According to the experts, the word punishment has a punitive meaning, with a socially constructed meaning of association of teachers' violence against students, and can prevent a response that meets the criterion of scientific validity.

Only one pre-test of the Self-Answered Questionnaire for teachers was enough to reach the final version, and the Committee of Judges proposed any changes.

As for the Observation Guide, there was agreement among the judges that the changes were significant in their semantic content and that a new back-translation should be carried out, with application in the country of origin; and there should be approval of the authors of the original version of the instrument. 
Chart 1. Rodadas de Avaliação Qualitativa no Comitê de Juízes da (Qualitative Evaluation Round at the Committee of Judges of the) Encuesta de constatación y reflexión del sexismo en el ámbito escolar and Cuestionario autoadministrado de constatación y reflexión del sexismo en el ámbito escolar, of Noralidys Washington (2015). Rio de Janeiro State, 2017.

\begin{tabular}{|c|c|c|}
\hline $\begin{array}{c}1^{\text {a }} \text { rodada do Comité de Juízes } \\
\text { (Após V1-1 e V1-2) } \\
\text { (1 }{ }^{\text {st }} \text { round of the Committee of Judges, after } \\
\text { V1-1 and V1-2) }\end{array}$ & $\begin{array}{l}2^{\mathrm{a}} \text { rodada - Após } 10 \text { pré-teste } \\
\left(2^{\text {nd }} \text { round- After the } 1^{\text {st }} \text { pre-test }\right)\end{array}$ & $\begin{array}{c}\text { Tradução reversa do português brasileiro } \\
\text { para o espanhol cubano (Back-translation } \\
\text { into Cuban Spanish) }\end{array}$ \\
\hline \multicolumn{3}{|c|}{ A. Relação entre alunos e alunas (Relationship among students) } \\
\hline $\begin{array}{l}\text { 1. To draw the distribution of boys and girls } \\
\text { throughout the classroom (...) }\end{array}$ & $\begin{array}{l}\text { To draw the distribution of boys and girls } \\
\text { throughout the classroom (...) }\end{array}$ & $\begin{array}{l}\text { Dibuja la distribución de niñas y niños en el } \\
\text { aula. Puede utilizar A para las niñas y O para } \\
\text { los niños. }\end{array}$ \\
\hline 3. Observation of interactions in the break & Observation of interactions in the break & Observe las interacciones en el recreo \\
\hline $\begin{array}{l}\text { 3-g) Real sentimental demonstrations have } \\
\text { been observed between: }\end{array}$ & $\begin{array}{l}\text { Real sentimental demonstrations have been } \\
\text { observed between: }\end{array}$ & $\begin{array}{l}\text { ¿Has observado muestras afectivas } \\
\text { concretas entre: }\end{array}$ \\
\hline 1. Present $\mathrm{A} / \mathrm{O}: \mathrm{S} N$ & 1. $(\ldots)$ & 1. Presente $\mathrm{A} / \mathrm{O}: \mathrm{S} N$ \\
\hline 2. Intensity: M P (*a, b, c, d, e) & $\begin{array}{l}\text { 2. Intensity: }(\ldots) \\
\mathrm{N}(* \ldots f, g)\end{array}$ & 2. Intensidad: M P (*a, b, c, d, e, f, g) \\
\hline \multicolumn{3}{|c|}{ B. Atitude dos(as) professores(as) para com os(as) alunos(as) (Attitude of teachers towards students) } \\
\hline $\begin{array}{l}\text { 1. In relation to the tone of voice they use } \\
\text { to address their students } \\
\text { O/A___ Strong___ Smooth }\end{array}$ & $\begin{array}{l}\text { In relation to the tone of voice }{ }^{4}(. .) D / S \\
{ }^{4} \text { Voice intonation change upwards [strong] } \\
\text { and downwards [smooth] }\end{array}$ & $\begin{array}{l}\text { Con relación al tono de } \mathrm{voz}^{4} \text { que usan para } \\
\text { dirigirse a los alumnos y alumnas } \\
\text { O/A -Fuerte - Suave } \\
\text { Cambios en la entonación de la voz para } \\
\text { encima [fuerte] y para abajo [suave] }\end{array}$ \\
\hline $\begin{array}{l}\text { 5. Are there differences in punishments to } \\
\text { the students? S N N/A }\end{array}$ & $\begin{array}{l}\text { Is it observed if there are disciplinary } \\
\text { actions to students? S N } \\
\text { (If YES, answer the item a). } \\
\text { a) Are there differences in disciplinary } \\
\text { actions to boys and girls? S N (If YES: } \\
\text { What differences? }\end{array}$ & $\begin{array}{l}\text { ¿Observe si hay aplicación de medidas } \\
\text { disciplinarias a los/as alumnos/as? S N } \\
\text { En caso a respuesta sea SI, observar las } \\
\text { diferencia en las medidas disciplinares } \\
\text { aplicadas entre A/O }\end{array}$ \\
\hline \multicolumn{3}{|c|}{ C. Atitude dos(as) alunos(as) para com os(as) professores(as) (Attitude of students towards teachers) } \\
\hline $\begin{array}{l}\text { 1. They are more communicative when they } \\
\text { address the teacher: }\end{array}$ & Sem modificação (Without modification) & Sem modificação (Without modification) \\
\hline $\begin{array}{l}\text { 4. Positive reinforcemnt is more effective } \\
\text { with: } \\
\end{array}$ & Sem modificação (Without modification) & Sem modificação (Without modification) \\
\hline
\end{tabular}


Continued Chart 1.

19 rodada do Comité de Juízes

(Após V1-1 e V1-2)

( $1^{\text {st }}$ round of the Committee of Judges, after V1-1 and V1-2)

Final observations:

\section{Caption}

The italicized texts were additions to the instrument

Presente (Present):

$\mathrm{S}-\mathrm{Si} / \mathrm{Sim}(\mathrm{Yes})$

$\mathrm{N}-\mathrm{No} / \mathrm{Não}$ (No)

N/O - Não Observado/No Observado (Not observed)

Intensidad/Intensidade (Intensity):

M - Mucha/Muita(o) (Many)

$\mathrm{P}-\mathrm{Poca} / \mathrm{Pouca} / \mathrm{o}$ (Few)

N-Nenhuma (None)

NA - No se aplica/Não se aplica (Not Applied)

Códigos (Codes): ${ }^{1} A=$ abraços (hugs), $P A=$ palavras amáveis (kind words), $E P=$ expressões positivas (positive expressions), $T S$ =toque suave (soft touch), TF=toque forte (strong touch), $O=$ outras (others). $D / S=$ depende da situação (depends on the situation) 2a rodada - Após 10 pré-teste

( $2^{\text {nd }}$ round- After the $1^{\text {st }}$ pre-test)
Sem modificação (Without modification)
Tradução reversa do português brasileiro para o espanhol cubano (Back-translation into Cuban Spanish)

Sem modificação (Without modification)

(*a, b, c, d, e, $f, g$ )

a. Niños y niñas/Meninos e meninas (Boys and girls)

b. Niños y niños/Meninos e meninas (Boys and girls)

c. Niñas y niñas/Meninos e meninas (Boys and girls)

d. Niños y profesor(a)/Meninos e meninas

(Boys and teacher)

e. Niñas y profesor(a)/ Meninos e meninas

(Girls and teacher)

f. Meninos e outras pessoas da escola

inspetorr, coordenador, diretor e outros)/

(Niños y otras persona de la escuela

(Director, subdirector y otras)(Boys and

other people from school (monitor,

coordinator, principal and others)

g. Meninas e outras pessoas da escola

(inspetor, coordenador, diretor e outros/

(Niña y otras persona de la escuela

(Director, subdirector y otras) (Girls and

other people from school (monitor,

coordinator, principal and others)

The changes, after application in a Cuban school and consensually analyzed by the authors and observers, concluded that los instrumentos se ajustan a los objetivos de la investigación. Si considero que fue factible aplicarlo por separado al receso en las clases Ahora con más especificidad mejora la observación.

The translation of this version of Cuban Spanish from the Observation Guide into Brazilian Portuguese was applied again in a Brazilian school, obtaining the following editorial improvements in three more rounds of evaluation by experts. For some items, they added the expressions not observed and sentimental demonstrations. Item II.5 has been restructured to include other types of disciplinary actions such as warning, attention call and punishment.

In the last round of the Committee of Judges, changes were proposed in question III.1, to include the word both and the expression not observed, in the item about the demand for attention and communication interaction between student/ teacher. In question III.4, on the reaction to the positive reinforcement of teacher, for the answer yes, in addition to both and not observed, was included explanatory note with the following terms: thank you, thank you very much, cool, that's so cool, nice, non-verbal expressions like smiles or others. For the negative answer, terms such as I disagree, that's boring, non-verbal expressions like grimaces or others, provided more qualitative specificity to the response.

The observation of boys and girls interacting among partners and with the teacher in the physical education class generated the need to include positive and negative responses when observed aspects related to positive reinforcement. Said the observers on the Committee of Judges - I was able to observe varied responses, both positive and negative. Yes, there are also verbal and non-verbal responses.

Finally, the possibility of registering insights on the environment and the decoration of the space was incorporated in the final observations. Thus, it was justified by one of the judges that the environment allows to see images that can transmit gender stereotypes.

There were modifications of nine questions from the original version of the Observation Guide in four rounds of qualitative evaluation by the Committee of Judges until the final version of the guide was translated culturally and adapted to Brazilian Portuguese. In addition, in the Brazilian version, the two instruments of the original version (SAQ and Observation Guide) were converted into three instruments: the teacher SelfAnswered Questionnaire, and two Observation Guides, one for classroom and another for the break. The full instrument is attached to this article (Annex 1 and 2). 


\section{DISCUSSION}

Translation, back-translation and cultural adaptation of instruments produced in another language and other cultural contexts was a complex process that required four rounds of evaluation in the Committee of Judges and application of three pre-tests; besides reading by the author of the instrument, so that the modifications were more adaptive than structural. Particularly, instruments that seek to grasp identity, relationships, roles, and gender stereotypes, require qualitative validity and cultural adequacy.

Studies that use these procedures to obtain reliable research instruments to apply in schools with children in the fields of health, nursing and education are often found in the Brazilian scientific literature. Mostly, they use quantitative approaches by applying statistical tests to reach a final version. ${ }^{11-16}$ The particularity of the process developed in this article was the scientific validity of the instruments, based on rounds of qualitative evaluation, since observers joined the Committee of Judges and were able to bring their insights and experiences from the natural environment of the pre-test when they were observing.

In the Self-Answered Questionnaire for teachers, a single application was enough to validate it in a qualitative manner, with some adjustments of semantics, not content. However, the application of the Observation Guide in two separate instruments represented a substantial change in the format of the instrument, with slight adjustments of back-translated content into Cuban Spanish and approved by the instrument's authors.

This whole process ensured qualitative consistency to the instruments and responded to the methodological foundation of a new pre-test version. After successive corrections and changes suggested with the pre-test, the final version of the instrument was obtained. ${ }^{14}$ It is important to note that qualitative evaluations by experts, accompanied by a movement of approximation-distance from the field of application of the pre-test, and the participation of observers in the Committee of Judges, is fundamental for the production of scientifically valid instruments until any changes are necessary.

The acceptance of modifications in the instruments was discussed and approved by the of Judges, in all rounds, based on the knowledge and experience of experts, cultural characteristics of Brazilian schools and the concordance between observations.

The expression, punishment, has been replaced by disciplinary actions, because in Brazil this term is related to corporal punishment, ${ }^{15}$ and to researches that declare punishment as a punitive action and linked to violence ${ }^{15,16}$

Another example was the question III.1 that addresses the topic of communication, resulting in two items, one on the demands of attention and another on the interaction. The experts have rescued the relational dimension of communication that marks the standards of interaction and type of bond established between partners. ${ }^{17}$

The results of the steps, translation and back-translation, show congruence between the versions produced. However, the versions after being reviewed in the rounds, by the Committee, need to be culturally adapted.

\section{CONCLUSIONS AND IMPLICATIONS TO THE PRACTICE}

The methodological research allowed obtaining three culturally adapted instruments for diagnosis of gender construction in childhood in elementary schools in Brazil and primary in Spanish-speaking countries. The depth of the modified items allowed to obtain results that can be used in the Brazilian context, but can also be analyzed to introduce changes in the original Spanish-language version for its future application.

The present study may be a possibility of methodological validation of instruments elaborated in other languages and cultures, in the crossing of experts' knowledge with the approaches and distances of the interobserver in the field of observation. It is possible to use culturally adapted and validated instruments, using qualitative approaches, as happened with the Observation Guide. The changes improved the depth, consistency of observations by different observers and introduced more specific features to the versions for application in future nursing and education research.

The final versions of both instruments can make their application easier in the research on gender in childhood to diagnose interactional situations and contribute to the development of health promotion actions at School. In addition, they may be used with these variants in other countries from the perspective of multi-centre studies.

The limits of the methodological study refer to the quantitative validity, considering the nature of the gender theme in its complexity in order to quantify it.

\section{Financial support}

National Postdoctoral Fellowship granted by the Coordination for the Improvement of Higher Education Personnel (CAPES) to the first author. Dean of Extension of the Federal University of Rio de Janeiro, PROFAEX Notice № 128/2017 - Programa Institucional de Fomento Único de Ações de Extensão (Institutional Program for Single Promotion of Extension Actions).

\section{ACKNWOLEDGMENTS}

I wish to thank Professor Cássia Tavares, Yolanda Condorimay, Maria da Graça Corso da Motta, Brenda Morales, Tania del Pino Más, Noralydis Rodríguez Washington, Anabel Lozano Lefrán, Claudia Braña Capote and Glendy Martin Sánchez because of their participation as appliers of the instruments.

\section{REFERENCES}

1. Mead M. Sexo e temperamento. Série Debates Antropologia. 4ํㅜ ed. São Paulo: Perspectiva; 2000. 131 p.

2. Whitaker DCA. Menino - Menina: sexo ou gênero? In: Aerbino RV, Grande MA, org. A escola e seus alunos: o problema da diversidade cultural. 1aㅡ. ed. São Paulo: Unesp; 1995. p.31-52. 
3. Mimbrero Mallado C. Un modelo de análisis de la cultura de género en las organizaciones. Int J Develop Educ Psychol [Internet]. 2014; [cited 2017 Nov 27]; 6(1):167-74 Available from: http://www.infad.eu/ RevistaINFAD/OJS/index.php/IJODAEP/article/view/730

4. Silva ER. Avaliação no ensino superior: a influência do sexo na avaliação na formação inicial de professores. Rev Int Form Professores (RIFP) [Internet]. 2017; [cited 2017 Nov 22];2(2):14-33. Available from: http://itp.ifsp.edu.br/ojs/index.php/RIFP/article/view/662/676

5. Morin-Messabel C, Ferrière S, Lainé A, Mieyaa $Y$, Rouyer V. Representações das categorias de sexo em crianças no contexto escolar. Cad Pesqui [Internet]. 2016 Apr/Jun; [cited 2017 Nov 21]; 46(160):52646. Available from: $h$ ttps://dx.doi.org/10.1590/198053143624

6. Menezes $A B C$, Brito RCS. Diferenças de gênero na preferência de pares e brincadeiras de crianças. Psicol Reflex Crít [Internet]. 2013 [cited 2017 Nov 21]; 26(1):193-201. Available from: https://dx.doi. org/10.1590/S0102-79722013000100021

7. Cruz TM. Gênero e culturas infantis: os clubinhos da escola e as trocinhas do Bom Retiro. Educ Pesqui [Internet]. 2012 Jan/Mar; [cited 2017 May 3]; 38(1):63-78. Available from: https://dx.doi.org/10.1590/ S1517-97022012005000004

8. Senkevics AS, Carvalho MP. O que você quer ser quando crescer? Escolarização e gênero entre crianças de camadas populares urbanas. Rev Bras Estud Pedagog [Internet]. 2016; [cited 2017 Nov 21]; 97(245):179-94. Available from: https://dx.doi.org/10.1590/S2176$6681 / 380613879$

9. Rebollo Catalán MÁ, García Pérez R, Piedra J, Vega L. Diagnóstico de la cultura de género en educación: actitudes del profesorado hacia la igualdad. Rev Educ [Internet]. 2011 May/Aug; [cited 2017 Feb 21] 355:521-46. Available from: http://www.revistaeducacion.educacion. es/re355/re355_22.pdf

10. Torres Esperón JM, Lozano Lefrán A, Rodríguez Washington $\mathrm{N}$. Formación de promotores por la equidad de género desde la infancia. Rev Cubana Salud Pública [Internet]. 2013; [cited 2017 Jan 21]; 39(Suppl 1):893-902. Available from: http://scielo.sld.cu/scielo. php?script=sci_arttext\&pid=S0864-34662013000500008\&lng=es
11. Guillemin F, Bombarbier C, Beaton D. Cross-cultural adaptation of healthy-related quality of life measures: literature review and proposed guidelines. J Clin Epidemiol [Internet]. 1993 Dec; [cited 2017 Jan 21]; 46(12):1417-32. Available from: https://www.ncbi.nlm.nih.gov/ pubmed/8263569

12. Arrue AM, Neves ET, Magnag TSBS, Cabral IE, Gama SGN, Hökerberg YHM. Tradução e adaptação do Children with Special Health Care Needs Screener para português do Brasil. Cad Saúde Pública [Internet]. 2016 Jun; [cited 2017 Jan 21]; 32(6):e00130215. Available from: http:// www.scielo.br/scielo.php?script=sci_arttext\&pid=S0102-311X201600 0604002\&lng=en\&nrm=iso

13. Rodrigo J, Cruz DALM, Tesoro MG, Lopes MHBM. Traducción y adaptación cultural para Brasil del modelo Developing Nurses' Thinking. Rev Latino Am Enferm [Internet]. 2014 Mar/Apr; [cited 2017 May 17]; 22(2):197-203. Available from: http://dx.doi.org/10.1590/01041169.3232 .2402

14. Andrade RC, Leite ACAB, Alvarenga WA, Martimiano RR, Santos CB, Nascimento LC. Translation and cultural adaptation of the Needs of Parents Questionnaire (NPQ) to be used in Brazil. Esc Anna Nery [Internet]. 2018 Nov; [cited 2017 Nov 25]; 22(1):e20170104. Available from: http://dx.doi.org/10.1590/2177-9465-ean-2017-0104

15. Projeto de Lei 7672 . Educação sem uso de castigos corporais. Altera a Lei № 8.069, de 13 de julho de 1990, que dispõe sobre o Estatuto da Criança e do Adolescente. [Internet], Brasília (DF); 2010 [cited 4 May 2017]. Available from: http://www.camara.gov.br/proposicoesWeb/fic hadetramitacao?idProposicao $=483933$

16. Ribeiro JM. O uso do castigo físico em crianças e adolescentes como prática educativa: algumas perspectivas da Sociologia, Filosofia e Psicologia. Pesqui Prát Psicossociais [Internet]. 2014 Dec; [cited 2017 May 17]; 9(2):213-21. Available from: http://pepsic.bvsalud.org/scielo. php?script=sci_arttext\&pid=S1809-89082014000200007\&lng=pt\&nr $\mathrm{m}=$ iso

17. Anzorena O. El arte de comunicarnos: Conceptos y técnicas para una comunicación interpersonal efectiva. $1^{\underline{a}}$ ed. Buenos Aires: Ediciones Lea; 2016. p. 15.

\section{SUPPLEMENTARY MATERIAL}

The following online material is available for this article:

Annex 1 - Instrumento de Observación y Cuestionario Auto administrado.

Annex 2 - Instrumento de Observação e Auto resposta. 